\title{
Evaluation of Chrysanthemum (Dendranthema grandiflora Tzvelev) Genotypes for Floral and Quality Traits under Hill Zone of Karnataka, India
}

\author{
S. Roopa ${ }^{1^{*}}$, S.Y. Chandrashekar ${ }^{1}$, M. Shivaprasad ${ }^{2}$, \\ L. Hanumantharaya ${ }^{3}$ and Hemanth Kumar ${ }^{4}$ \\ ${ }^{1}$ Department of FLA, ${ }^{2}$ Department of NRM, ${ }^{3}$ Department of Entomology, COH, Mudigere, \\ Karnataka, ${ }^{4}$ Department of FLA, COH,Hiriyur, Karnataka \\ *Corresponding author
}

\section{A B S T R A C T}

Twenty varieties of chrysanthemum were evaluated with an aim to identify suitable varieties based on different characters under hill zone of Karnataka. The experiment was

Keywords

Genotypes,

Chrysanthemum, Flowering

Article Info

Accepted:

12 July 2018

Available Online:

10 August 2018 carried out in Randomized Complete Block Design with three replications at the experimental block of Department of Floriculture and Landscape Architecture, College of Horticulture, Mudigere, Karnataka during 2017-2018. The results revealed that genotype Kolar Local recorded minimum days for appearance of first flower and 50 percent of flowering (90.59 and 99.66 respectively.) and maximum flowering duration and crop duration (149.33 days and 239.55 days, respectively) whereas, genotype Sharad Mala recorded the maximum days for first flower appearance and 50 percent flowering (149.08 and 169.35, respectively) and minimum flowering duration and crop duration (45.43days and 190.29 days, respectively). The genotype Kolar Local recorded significantly maximum girth of the flower stalk $(5.04 \mathrm{~mm})$, flower diameter $(5.75 \mathrm{~cm})$, individual flower weight (3.24g) and number of ray florets per flower (325.14). The genotype Kolar Local manifested maximum shelf life and vase life (9.54 days and 15.17 days, respectively) whereas, the minimum was observed in genotype Autumn Joy (2.39days and 5.22days, respectively.)

\section{Introduction}

Chrysanthemum (Dendranthema grandiflora T.) is one of the most important flower crops grown commercially in India for cut and loose flowers and is also used for garden display. It is commonly known as Guldaudi, Autumn Queen or Queen of the East belongs to the family Asteraceae. Growth of chrysanthemum has two distinguished phases, firstly a period of long day conditions (day length more than $12 \mathrm{hrs}$ ) where the plants grow vegetatively and secondly short day conditions (daylengths less than $12 \mathrm{hrs}$ ), leading to flower induction and development. Long day and short day conditions are influenced by season and climatic conditions of that particular region. The variations among chrysanthemum varieties are large in response to environment particularly temperature and the interaction 
between temperature and cultivar occur for every developmental trait. Therefore, varietal evaluation became necessary to identify the suitable variety for the specific region. The performance of any crop or variety largely depends on interaction between genotype and environment. As a result, varieties, which perform well in one region, may not perform same in other regions of varying climatic conditions. Hence, it necessary to evaluate new genotypes for their quality traits under varying climatic conditions.

\section{Materials and Methods}

The experiment was carriedout at College of Horticulture, Mudigere, Karnataka during 20172018. Twenty genotypes of chrysanthemum were evaluated. The varieties include T1: Red T2: Pink Clad, T3: Pache, T4: Star Pink, T5: Poornima White, T6: Paper Yellow, T7: White Pink, T8: Chandini, T9: White Prolific, T10: Pink, T11: Sharadmala, T12: Paper White, T13: ACC1, T14: Kolar Local (Marigold), T15: Winter Queen, T16: Ratnam Selection, T17: Dundi, T18: Autumnjoy, T19: Violet, T20: Poornima Yellow.

The experiment was laid out in RCBD with three replication. Plant spacing between two rows was $30 \mathrm{~cm}$ and within plant $30 \mathrm{~cm}$. The observations were recorded at regular intervals and uniform package and practices were followed throughout the cropping season.

\section{Results and Discussion}

Data pertaining to flowering characters like days taken for appearance of first flowering, days taken for 50 percent flowering, duration of flowering and duration of crop are furnished in table 1 .

Among the different genotypes studied, the genotype Kolar Local recorded minimum days for appearance of first flower (90.59) and days for 50 percent of flowering (99.66) whereas, genotype Sharad Mala recorded the maximum days for first flower appearance (149.08) and daysfor50 percent flowering (169.35). The variation in time taken for flowering might be due to the genetic makeup of the genotype or the influence of genotype and environment. The variation in time to flowering of different chrysanthemum genotypes was also reported by Dilta et al., (2005), Srilatha et al., (2015) and Suvija et al., (2016) in chrysanthemum.

The genotype Kolar Local recorded maximum flowering duration (149.33 days) and crop duration (239.55 days) whereas, genotype Sharad Mala recorded minimum flowering duration (45.43days) and crop duration (190.29 days). The variation induration of flowering and crop among the varieties was attributed to genotype of the plant and environmental influence. Similar results were reported by Rajiv et al., (2007), Kishan et al., (2007) Peddi et al., (2008), Kumar (2011) and Suvija et al., (2016) in chrysanthemum.

The data pertaining to flower quality characters of different genotypes of chrysanthemum are provided in table 2 . The genotype Kolar Local recorded significantly maximum girth of the flower stalk (5.04 $\mathrm{mm})$, flower diameter $(5.75 \mathrm{~cm})$, individual flower weight $(3.24 \mathrm{~g})$ and number of ray florets per flower $(325.14)$.

Whereas, minimum girth of the flower stalk $(2.28 \mathrm{~mm})$, flower diameter $(3.27 \mathrm{~cm})$, flower weight $(0.92 \mathrm{~g})$ and number of ray florets (37.36) was found in the genotype Pink Cloud. The variation among the genotypes was may be due to flower size of the genotype. Similar type of variations was observed by Beeralingappa (2016) and Suvija et al., (2016) in chrysanthemum. 
Table.1 Performance of chrysanthemum genotypes for flowering parameters

\begin{tabular}{|c|c|c|c|c|c|}
\hline $\begin{array}{l}\text { Sl. } \\
\text { No. }\end{array}$ & Genotypes & $\begin{array}{l}\text { Days taken for } \\
\text { appearance of first } \\
\text { flowering }\end{array}$ & $\begin{array}{l}\text { Days taken } \\
\text { for50 per cent } \\
\text { flowering }\end{array}$ & $\begin{array}{l}\text { Duration of } \\
\text { Flowering } \\
\text { (days) }\end{array}$ & $\begin{array}{l}\text { Duration of } \\
\text { the crop } \\
\text { (days) }\end{array}$ \\
\hline 1 & Red & 97.74 & 112.50 & 108.84 & 204.27 \\
\hline 2 & Pink Cloud & 96.48 & 118.88 & 105.30 & 201.33 \\
\hline 3 & Pache & 115.88 & 123.97 & 87.40 & 202.33 \\
\hline 4 & Star Pink & 127.55 & 132.98 & 104.59 & 230.44 \\
\hline 5 & Poornima White & 103.57 & 125.23 & 102.95 & 204.40 \\
\hline 6 & Paper Yellow & 112.44 & 130.22 & 105.30 & 217.49 \\
\hline 7 & White Pink & 130.51 & 148.76 & 74.37 & 208.16 \\
\hline 8 & Chandini & 115.17 & 129.51 & 123.31 & 228.41 \\
\hline 9 & White Prolific & 93.22 & 119.03 & 100.32 & 193.35 \\
\hline 10 & Pink & 92.64 & 103.06 & 118.40 & 211.00 \\
\hline 11 & Sharad Mala & 149.08 & 169.35 & 45.43 & 190.29 \\
\hline 12 & Paper White & 111.89 & 129.28 & 96.31 & 208.33 \\
\hline 13 & ACC 1 & 109.96 & 126.87 & 117.40 & 225.31 \\
\hline 14 & Kolar Local (Marigold) & 90.59 & 99.66 & 149.33 & 239.55 \\
\hline 15 & Winter Queen & 142.34 & 156.31 & 76.40 & 218.19 \\
\hline 16 & Ratnam Selection & 115.18 & 123.93 & 102.29 & 214.99 \\
\hline 17 & Dundi & 93.19 & 102.87 & 119.43 & 213.42 \\
\hline 18 & Autumn Joy & 99.74 & 115.94 & 101.53 & 202.53 \\
\hline 19 & Violet & 101.86 & 117.57 & 81.33 & 202.45 \\
\hline 20 & Poornima Yellow & 111.27 & 129.61 & 86.00 & 215.29 \\
\hline & S. Em \pm & 3.70 & 3.45 & 4.08 & 6.84 \\
\hline & $\mathrm{CD}$ at $5 \%$ & 10.59 & 9.89 & 11.69 & 19.50 \\
\hline
\end{tabular}


Table.2 Performance of chrysanthemum genotypes forflower quality parameters

\begin{tabular}{|c|c|c|c|c|c|}
\hline $\begin{array}{l}\text { Sl. } \\
\text { No. }\end{array}$ & Genotypes & $\begin{array}{l}\text { Girth of the flower } \\
\text { stalk }(\mathrm{mm})\end{array}$ & $\begin{array}{c}\text { Flower } \\
\text { diameter }(\mathrm{cm})\end{array}$ & $\begin{array}{c}\text { Flower } \\
\text { weight }(\mathrm{g})\end{array}$ & $\begin{array}{l}\text { Number of ray } \\
\text { florets per flower }\end{array}$ \\
\hline 1 & Red & 2.32 & 4.27 & 1.07 & 42.68 \\
\hline 2 & Pink Cloud & 2.28 & 3.27 & 0.92 & 37.36 \\
\hline 3 & Pache & 2.54 & 4.77 & 1.33 & 94.36 \\
\hline 4 & Star Pink & 3.43 & 5.34 & 3.18 & 155.58 \\
\hline 5 & Poornima White & 2.43 & 4.45 & 1.74 & 120.30 \\
\hline 6 & Paper Yellow & 2.52 & 4.24 & 1.65 & 129.59 \\
\hline 7 & White Pink & 2.41 & 3.54 & 2.40 & 142.64 \\
\hline 8 & Chandini & 4.58 & 4.29 & 1.28 & 159.24 \\
\hline 9 & White Prolific & 3.42 & 3.49 & 1.66 & 124.91 \\
\hline 10 & Pink & 2.45 & 3.82 & 1.44 & 117.30 \\
\hline 11 & Sharad Mala & 3.42 & 3.67 & 1.31 & 130.50 \\
\hline 12 & Paper White & 2.69 & 4.42 & 1.35 & 68.85 \\
\hline 13 & ACC 1 & 2.69 & 4.49 & 1.66 & 71.13 \\
\hline 14 & Kolar Local (Marigold) & 5.04 & 5.75 & 3.24 & 325.14 \\
\hline 15 & Winter Queen & 2.67 & 3.50 & 1.31 & 68.35 \\
\hline 16 & Ratnam Selection & 3.42 & 4.36 & 1.28 & 70.36 \\
\hline 17 & Dundi & 3.51 & 5.31 & 2.28 & 102.57 \\
\hline 18 & Autumn Joy & 3.41 & 3.71 & 0.99 & 69.29 \\
\hline 19 & Violet & 2.51 & 4.44 & 1.49 & 105.98 \\
\hline 20 & Poornima Yellow & 2.54 & 4.28 & 1.61 & 135.80 \\
\hline & S. Em \pm & 0.13 & 0.14 & 0.16 & 3.87 \\
\hline & $\mathrm{CD}$ at $5 \%$ & 0.37 & 0.39 & 0.45 & 11.08 \\
\hline
\end{tabular}


Fig.1 Performance of chrysanthemum genotypes for shelf life and vase life

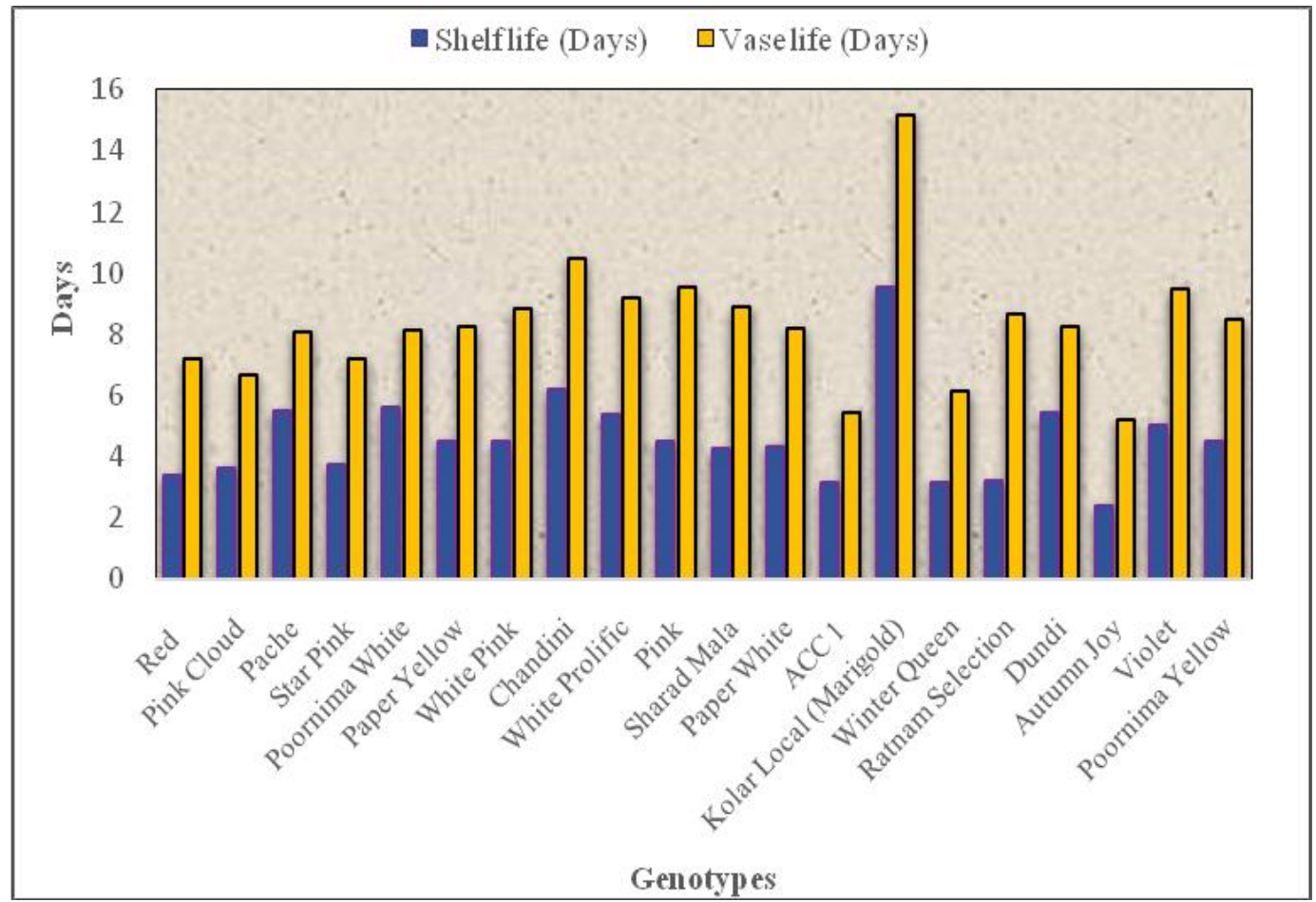

Plate.1 Best performing genotypes for flower quality traits.
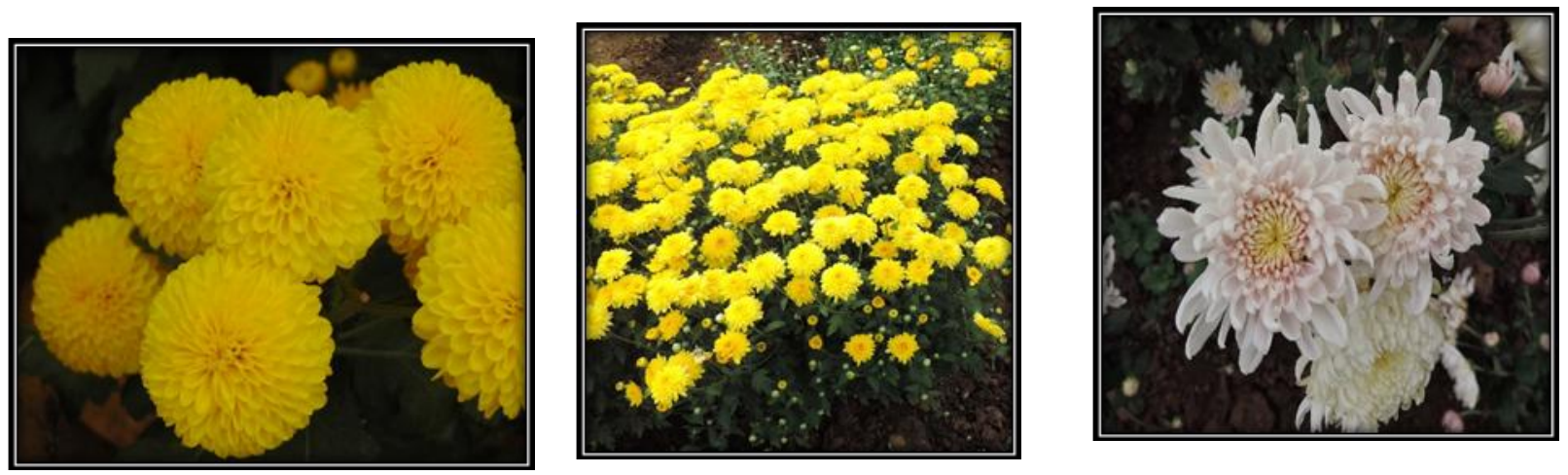

Shelf life and vase life of flowers varied significantly among the genotypes of chrysanthemum. Genotype Kolar Local manifested maximum shelf life and vase life (9.54 days and 15.17 days, respectively.) whereas, the minimum was observed in genotype Autumn Joy (2.39days and 5.22days, respectively.) which is represented in figure 1 . This variation may be due to different genetic makeup of genotypes and influenced by prevailing environmental conditions which affect the physiological processes of flower like cell turgidity, water loss through evapotranspiration and breakdown of the reserve food which governs the shelf life and vase life of the flower. Similar results were noted by Joshi et al., (2009), Beeralingappa (2016) in chrysanthemum. 
In conclusion, from this study it was concluded that genotype Kolar Local (Marigold) was early in flowering and can catch the early market advantage. However, it had good acceptance in the local market due to their colour and quality and suitable for successful cultivation under hill zone of Karnataka.

\section{References}

Beeralingappa, 2016, Morphological Characterization of Chrysanthemum genotypes under Central Dry Zone of Karnataka., M.Sc. (Horti) thesis, University of Agricultural and Horticultural Sciences, Shivamogga (India), pp 45-74.

Dilta, B. S., Sharma, Y. D. and Verma, V. K., 2005, Evaluation of chrysanthemum cultivars under subtropical region of Himachal Pradesh. J. Orn. Hort., 8(2): 149-151.

Joshi, M., Varma, L. R. and Masu, M. M., 2009, Performance of different varieties of chrysanthemum on flower yield under North Gujarat condition. J. Maharashtra. Agric. Univ., 34(2): 170-172.

Kishan, S., Prasad, K. V. and Raju, D. V. S., 2007, Evaluation of chrysanthemum (Dendranthema grandiflora Tzvelev) germplasm in winter season under
Delhi conditions. J. Orn. Hort., 11(1): 58-61.

Kumar, A., 2011, Evaluation of chrysanthemum varieties for loose flower production in Chhattisgarh plains. M. Sc. Thesis, IGKV, Raipur, pp 132-155.

Peddi, L., Pratap, M. and Reddy, S.A., 2008, Evaluation of yellow coloured chrysanthemum (Dendranthema grandiflora Tzvelev) cultivars for growth, flowering and yield. Orissa $J$. Hort., 36(1): 116-119.

Rajiv, K., Yadav, D. S. and ROY, A.R., 2007, Performance of chrysanthemum (Dendranthema grandiflora Tzvelev) cultivars under subtropical midhills altitude of Meghalaya. Environ. Ecol., 255 (Special 34): 941-944.

Srilatha, V., Sunil, K. K. and Deepthi, K. Y., 2015, Evaluation of chrysanthemum (Dendranthema grandiflora Tzvelev) varieties in southern zone of Andhra Pradesh. Agric. Sci. Digest., 35(2): 155-157.

Suvija, N.V., Kannan, M., Suresh, J. and Subesh, R.K., 2016, Evaluation of chrysanthemum (Chrysanthemum morifolium Ramat) genotypes for loose flower, cut flower and pot mums. Inter. J. Innov. Res. And $A d v$. Studies, 3(4): 100-103.

\section{How to cite this article:}

Roopa, S., Chandrashekar, S.Y., Shivaprasad, M., Hanumantharaya, L. and Hemanth Kumar. 2018. Evaluation of Chrysanthemum (Dendranthema grandiflora Tzvelev) Genotypes for Floral and Quality Traits under Hill Zone of Karnataka. Int.J.Curr.Microbiol.App.Sci. 7(08): 1874-1879. doi: https://doi.org/10.20546/ijcmas.2018.708.215 